\title{
両大戦間期日本綿織物の東南アジア進出
}

—蘭領東インドを中心に——

\section{村山良 忠}

1.はじめに

1930年代前半, 綿織物を中心とする日本製品は東南アジア市場に急速かつ大量に進 出した。このことは，世界恐慌下に扣ける列国の植民地再編の潮流とあいまって，進 出各地での日本製品流入阻止の動きを生み出した。このうち著名なるのに，1933年か ら日本と英領インドとの間で行なわれた通商交渉, いわゆる日印会商があるが(1), 東 南アジアでも日本と蘭領東インド, フィリピンとの間でそれぞれ通商交渉が持たれて いる。本稿は1930年代前半の急速な流入に至る日本製品の東南アジア進出を，綿織物 に焦点をあてて考察することにより，両大戦間期の日本と東南アジアの経済関係の一 側面を明らかにしようとするるのである(2)。

綿織物に焦点を置いたのは，それが日本の輸出にとっても，東南アジア各地域の翰 入にとっても大きな位置を占めた商品であるからである。日本綿業の発展にともない， 第一次大戦を契機として，1917年に綿織物は綿糸を抜いて生糸につぐ重要な輸出品と なった。1917年に批ける日本の輸出額に占める生系，綿織物，綿系の割合はそれぞれ $22.0 \% ， 8.0 \% ， 6.7 \%$ でった。その後1934年には，需要の減少しつつあった生系を 拔き，ついに綿織物は輸出品目中第 1 位を占めるに至った。1934年に括ける日本の輸 出額に占める綿織物, 生系の比率はそれぞれ $22.7 \%, 13.2 \%$ でる。むた東南アジア 各地域にとっても綿織物は，その需要を自給するだけ綿工業が発達していないため主 要輸入品の一つであった。例兄ば，1930年に批ける各地域の輸入品構成に占める綿織 物の割合は，フィリピン 9.5\%（第 2 位，綿製品を含むと $15.0 \%$ )，仏領インドシナ $18.8 \%$ (第 1 位)，タイ $17.0 \%$ (第 1 位), 蘭領東インド $14.3 \%$ (第 1 位)である(3)。

日本と東南フジアの経済関係を考察するにあたって，両者間の商品貿易に関する諸 問題は基礎的なもののうちに属していると思われる。しかしながら，この問題につい て論しているものは沃して多いとは言えない。それは一つに，この貿易関係が両者に とって占める位置が大きくなるのは，1930年以降の比較的短い期間であったことに由 
東南アジア一歴史と文化一 No. 11, 1982

来しているのであろう。しかもそれも日本からの輸出，すなわち東南てジア地域の側 にとっての輸入についてのみにすきない。日本から東南アジア地域への翰出は, 1929 年に 1 億 5,897 万円で翰出総額に占める割合は $7.4 \%$ であるが，それが1933年には 2 億 4,961万円，13.4\%に上昇する。それに対し翰入は，1929年に 1 億 6.742 万円，7.6 \%であったのが，1933年には1億 3,660万円とむしろ減少している。この結果，日本 の対東南アジア貿易は1930年以降，初めて黒字へと転換したのである。これを地域別 に見ると，1933年の日本の輸出全体に占める割合は蘭領東インド $8.5 \%$ ，英領マレー $2.5 \%$ ，フィリピン $1.3 \%$ ，タイ $1.0 \%$ ，仏領インドシナ0.2\%で，東南フジフ向け輸 出の63.1\%は，蘭領東インドに対するものである。

また各地域の輸入に占める日本の比率を, 蘭領東インド,フィリピン, タイについ て1929年と1933年で見てみよう。蘭領東インドでは10.6\%（第 5 位）から31.0\%（第 1 位)、フィリピンでは $4.3 \%$ か $2.8 \%$ (ともに第 2 位)(4)，タイでは8.1\% (第 4 位) から $15.8 \%$ (第 2 位)へと変化している。日本からの輸出留易については闌領東イン ドの地位が他の東南アジア地域に比して，日本にとっても蘭領東インドにとっても大 きいことがわかる。

この傾向は綿織物輸出に限れば一層顕著である。1933年に拈ける東南フジフ向け絑 織物輸出のその輸出総額に対する比率は28.1\%である(5)。その内訳は，蘭領東インド $20.4 \%$, 海峡植民地 $4.5 \%$ ，タイ $1.7 \%$ ，フィリピン $1.3 \%$ ブあり，東南フジア向けの 大半は蘭領東インド向けであることがわかる。また1933年のそれぞれの地域の綿皒物 輸入に占める日本の割合は，蘭領東インド $74.4 \%$ (第 1 位)，英領マレー $57.1 \%$ (第 1 位)(6)，タイ $48.4 \%$ (第 1 位)，フィリピン $35.8 \%$ (第 2 位)(7)である。いずれる日本 の占める位置が大きいが，とりわけ蘭領東インドで極めて大きいことがわかる。标稿 に拈いて主として蘭領東インドについて考察するのはこのことによる。

両大戦間期の日本と東南アジアの経済関係, あるいは留易関係は，これまで主とし て二つの時点で語られてきた。すなわちこれまで見たごとく，1930年代に日本䃒品は， その安価さを武器に急速に拡大し，その地を植民地化あるいは自国の市埸化していた 欧米諸国と対立したことについてが一つである。第 2 には，第一次世界大佬時に欧米 商品の不足に利して旧来その市場であった東南アジアに日本商品が進出したが，終馃 による欧米商品の復帰により日本商品は後退を余儀なくされたというものである。本 稿のとりあげる綿織物についてもそら考えられていると見てよいたろら。歴史的邪罗 としてはこの 2 点に問題はないと思う。問題は第一次世界大彼と1930年代との問の欠 落にある(8)。 
両大戦間期日本綿織物の東南アジア進出

つまり問題はこうなる。大戦の終結による欧米商品の復㷌により日本商品はいかた 後退したのか。それ以後1930年代に至るまで何があったのか。そしてそれは1930年代 の日本綿織物輸出の急激な増加と係わらないのか。換言すれば，1930年代の日本綿織 物の東南アジア進出は安価さがテュとなったことは明らかにせよ，それのみで生じた のかといらことである。

これまで日本の綿織物輸出の増大は，主として価格の問題として扱われてきた。日 本の綿織物が何故イギリスの綿織物と対抗し駆逐し得たかという問いに対し，低貨金 に根姏を置く論者も，生産性の向上に論拠を置く論者も等しくそれによる価格引き下 げ効果を念頭に置いている。つまり1930年代の綿織物輸出の増大は，低賃金であれ生 座性の向上であれ，それと為替の下落による価格の下落によるものである(9)。価格外 の要因としては製品の高度化，これは主として細系製品への傾向を示している，があ げられている(10)。本稿は日本製綿織物の安価さを否定するものではないし，生産構 造について論じるものではないのでこれ以上の言及は行なわない。しかし，ここで， 綿織物という商品がより安く，より高級化することで売れていくという形で論じられ ているといらことを確認しておこう。

結論を先取りするならば，本稿は晒，染色などの織物加工業の発達を前提として洒 格の下落が機能し，1930年代の日本製綿織物の東南アジア進出が実現したのだ，とい らことを主張するすのである。加工業の発展についてふれたものはないわけではない し，晒綿布といら商品について言及していないわけであない。しかしそれは多く付随 的に述べられている。本稿は, 晒綿布をはじめとする加工綿布が生地綿布とは, 綿織 物と綿系ほどの差はないにせよ，製品レベルの異なったものであるということに重点 を和き，その観点から1930年代の進出を考察する。

\section{2.日本綿織物輸出と東南アジア市場}

ここで1930年代に東南アジア市場が脚光を浴びるに至るまでの推移を簡単に見てお こう。まえにも見たように，日本の綿織物輸出は第一次世界大戦を契機として堌大し た。このときから1920年代末までの主要な市場は中国市場である。しかし中国市場は 1920年代中葉を過ぎると綿織物輸出に占める割合のみならず，金額的にも減少傾向に はいり，1930年代にはいると急速に減少する。その原因については，日貨排斥，関税 自主権獲得による高関税, 在華紡の発展による中国市場の讓渡, などがあげられてい る。こうして，1920年代半ばから中国市場にかわるものとしてインド市場が成長して くる。しかし，インド市場は宗主国イギリスの主要な綿織物市場であるばかりでなく， 
東南アジフ一歴史と文化一 No. 11, 1982

第1困 日本の綿布輸出の国別推移 1 第 2 図 日本の綿布輸出の国別推移 2
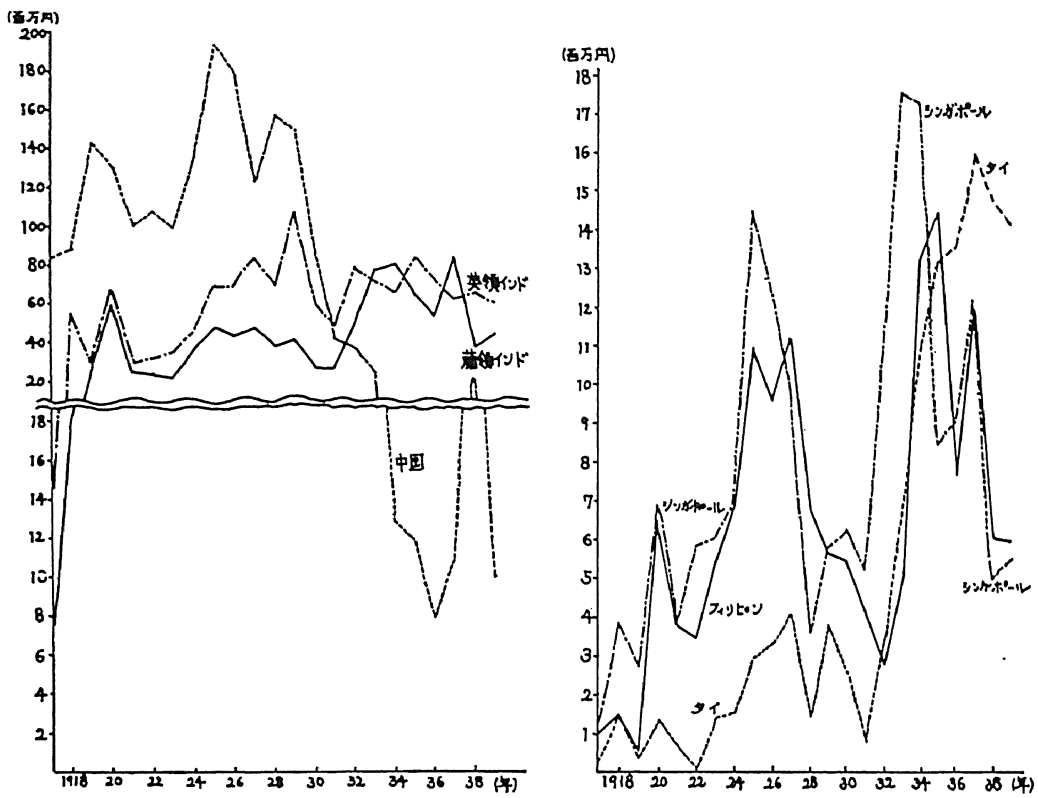

成長しつつあったインド綿工業の市場ですあった。日本製綿織物は大きな差别関税に 悩まされ，最終的には日印会商の協定によりインド市場への流入を制限されることに なった。かくして，1930年代に，日本綿製品は東南アジア市場へと進出することにな る。

これが日本の綿織物輸出総体の動きを概観したものであるが，では何故，距離的に 近い東南アジア市場に先行して大きな抵抗の予測されるインド市場に進出したのたる らか。市場が大きいからだろらか。抵抗の大きさを考えるならばまず㸃南アジアに 進出し，しかる後インド市場に進出するのが順当と言うべきであろう。何故か。答は 簡単である。実際はそうなっていたのである。その鍵は1920年代までの主力商品は生 地綿布であったことにある。生地綿布に限って言えば，1920年代半ばまでに東南アシ ア市場への進出はほぼ完了していたのである。

これを見るまえに，日本綿織物の東南アジア市場への進出を見て扰くことにしよら。 第 1 表から第 3 表は，東南アジアを中心に日本の綿織物輸出の推移を装わしたもので ある。第 1 図，第 2 図は第 1 表をグラフ化したものである(11)。日本の綿蟣物輸出総 
両大戦間期日本綿變物の東南アジア進出

第 1 表 東南アジア諸国を中心とする日本の綿布輸出仕向国別推移

金 積

(千円)

\begin{tabular}{|c|c|c|c|c|c|c|c|c|c|}
\hline & & 菓イン領 & フィリピン & タ & 海 埴 & $\begin{array}{l}4 \text { 地域 } \\
\text { 尛 }\end{array}$ & 中 & $1 ン ト$ & 尌 \\
\hline 1912 ( T. & . 1) & 192 & 558 & 102 & 249 & 1,101 & 12,717 & 732 & 25,761 \\
\hline $13 C$ & 2) & 232 & 545 & 112 & 274 & 1,163 & 18,964 & 1,031 & 33,605 \\
\hline 14( & 3) & 183 & 308 & 60 & 212 & 763 & 26,188 & 1,727 & 34,840 \\
\hline 15( & 4) & 428 & 247 & 67 & 338 & 1,080 & 27,331 & 3,703 & 38,511 \\
\hline 16( & 5) & 2,245 & 277 & 179 & 757 & 3,458 & 34,783 & 10,560 & 60,050 \\
\hline 17( & 6) & 5,701 & 1,066 & 382 & 1,359 & 8,508 & 84,804 & 15,121 & 148,108 \\
\hline 18( & 7) & 17,693 & 1,547 & 1,544 & 3,900 & 24,684 & 88,047 & 55,435 & 268,640 \\
\hline 19( & 8) & 24,415 & 505 & 334 & 2,742 & 27,996 & 143,283 & 29,507 & 351,195 \\
\hline $20 C$ & 9) & 60,465 & 6,551 & 1,362 & 6,949 & 75,327 & 130,515 & 67,289 & 352,173 \\
\hline 21( & 10) & 25,571 & 3,779 & 609 & 3,841 & 33,800 & 100,987 & 30,465 & 203,673 \\
\hline 22( & 11) & 24,937 & 3,452 & 48 & 5,892 & 34,329 & 108,757 & 33,567 & 222,052 \\
\hline 23( & 12) & 22,584 & 5,398 & 1,432 & 6,048 & 35,462 & 100,292 & 36,546 & 234,227 \\
\hline 24( & 13) & 37,194 & 6,895 & 1,563 & 6,910 & 52,562 & 137,920 & 46,916 & 326,587 \\
\hline 25( & 14) & 49,372 & 10,921 & 2,929 & 14,559 & 77,781 & 194,012 & 70,394 & 432,850 \\
\hline $26(\mathrm{~S}$. & . 1) & 44,520 & 9,580 & 3,310 & 12,352 & 69,762 & 180,076 & 70.346 & 416,254 \\
\hline 27( & 2) & 49,228 & 11,210 & 4,137 & 9,892 & 74,467 & 123,634 & 85,957 & 382,806 \\
\hline 28( & 3) & 39,275 & 6,797 & 1,359 & 3,519 & 50,950 & 158,497 & 70,185 & 352,217 \\
\hline 29( & 4) & 42,283 & 5,629 & 3,815 & 5,797 & 57,524 & 150,115 & 109,138 & 412,706 \\
\hline 30( & 5) & 28,284 & 5,438 & 2,581 & 6,283 & 42,586 & 86,914 & 61,216 & 272,116 \\
\hline 31( & 6) & 28,279 & 4,161 & 795 & 5,212 & 38,447 & 43,073 & 49,865 & 198,731 \\
\hline 32( & 7) & 50,228 & 2,768 & 3,288 & 11,229 & 67,513 & 38,229 & 80,653 & 288,712 \\
\hline 33( & 8) & 78,269 & 5,103 & 6,778 & 17,607 & 107,757 & 25,604 & 71,431 & 383,215 \\
\hline 34( & 9) & 82,828 & 13,205 & 10,818 & 17,394 & 124,245 & 13,029 & 66,814 & 492,350 \\
\hline 35( & 10) & 66,577 & 14,492 & 13,226 & 8,494 & 102,789 & 11,912 & 85,181 & 496,097 \\
\hline 36( & 11) & 55,390 & 7,679 & 13,609 & 9,187 & 85,865 & 7,861 & 72,516 & 483,591 \\
\hline 37( & 12) & 85,702 & 12,056 & 16,088 & 12,230 & 126,076 & 11,295 & 63,040 & 573,064 \\
\hline $38 c$ & 13) & 39,485 & 6,052 & 14,899 & 5,053 & 65,489 & 23,910 & 67,878 & 404,239 \\
\hline 39( & 14) & 45,441 & 5,984 & 14,162 & 5,402 & 70,989 & 10,908 & 62,363 & 403,946 \\
\hline
\end{tabular}

(資料) 1912〜1916年は『海外市場に於ける本邦綿布』 1917〜1939年は『紡績事情参考畫』

よりそれぞれ作製。

（注） $1932(\mathrm{~S} .7)$ 年 3 月満州国建国により，33年以降中国から満州を分漼。

1934 (S.9) 年セイロン, 1937 (S.12) ビルマをそれぞれインドから分離。

頻のピークは，1920年と1925年にある。これを亨地域別に見れば，中国市場こそ1919 年にピークを迎えるものの，インド，東南アジア市場では一様に1920年にピークを有 している。このピークは第一次大戦を契機にインド，東南アジア市場に進出した日本 製綿織物が，欧米品が戻ってくる中で第一次大戦後の戦後恐慌による景気後退面に遭 遇したことにより生じたものである。1920年に比して1925年については各地域でかな りのばらつきが見られる。1925年のピークは最大の市場の中国がピークを見せたこと により生じたもので，インドでは29年，蘭䝨惊インドで熇原状のるのの27年，フィ リピン，タイでも27年にそれぞれピークが見られ，25年ピークが頙著なの海炏植民 
東南アジア一歷史と文化一 No. 11, 1982

第 2 表 続。同構成比

(\%)

\begin{tabular}{|c|c|c|c|c|c|c|c|c|c|}
\hline & & 䍘インド & フィリビン & 1 & 海植民地 & $\begin{array}{l}4 \text { 地域 } \\
\text { 訫 }\end{array}$ & 国 & インド & 総 \\
\hline 1912 ( $\mathrm{T}$. & 1) & 0.7 & 2.1 & 0.3 & 0.9 & 4.2 & 49.3 & 2.8 & 100.0 \\
\hline 13( & 2) & 0.6 & 1.6 & 0.3 & 0.8 & 3.4 & 56.4 & 3.0 & 100.0 \\
\hline 14( & 3) & 0.5 & 0.8 & 0.1 & 0.6 & 2.1 & 75.1 & 4.9 & 100.0 \\
\hline 15( & 4) & 1.1 & 0.6 & 0.1 & 0.8 & 2.8 & 70.9 & 9.6 & 100.0 \\
\hline 16( & 5) & 3.7 & 0.4 & 0.2 & 1.2 & 5.7 & 57.9 & 17.5 & 100.0 \\
\hline 17( & 6) & 3.8 & 0.7 & 0.2 & 0.9 & 5.7 & 57.2 & 10.2 & 100.0 \\
\hline 18( & 7) & 6.5 & 0.5 & 0.5 & 1.4 & 9.1 & 32.7 & 20.6 & 100.0 \\
\hline 19( & 8) & 6.9 & 0.1 & 0.0 & 0.7 & 7.9 & 40.7 & 8.4 & 100.0 \\
\hline 20( & 9) & 17.1 & 1.8 & 0.3 & 1.9 & 21.3 & 37.0 & 19.1 & 100.0 \\
\hline 21( & 10) & 12.5 & 1.8 & 0.2 & 1.8 & 16.5 & 49.5 & 14.9 & 100.0 \\
\hline 22( & 11) & 11.2 & 1.5 & 0.0 & 2.6 & 15.4 & 48.9 & 15.1 & 100.0 \\
\hline 23( & 12) & 9.6 & 2.3 & 0.6 & 2.5 & 15.1 & 42.8 & 15.6 & 100.0 \\
\hline $24 C$ & 13) & 11.3 & 2.1 & 0.4 & 2.1 & 16.0 & 42.2 & 14.3 & 100.0 \\
\hline $25 C$ & 14) & 11.4 & 2.5 & 0.6 & 3.3 & 17.9 & 44.8 & 16.2 & 100.0 \\
\hline 26 (S. & 1) & 10.6 & 2.3 & 0.7 & 2.9 & 16.7 & 43.2 & 16.8 & 100.0 \\
\hline $27 C$ & 2) & 12.8 & 2.9 & 1.0 & 2.5 & 19.4 & 32.2 & 22.4 & 100.0 \\
\hline 28( & 3) & 11.1 & 1.9 & 0.3 & 0.9 & 14.4 & 44.9 & 19.9 & 100.0 \\
\hline $29 C$ & 4) & 10.2 & 1.3 & 0.9 & 1.4 & 13.9 & 36.3 & 26.4 & 100.0 \\
\hline $30 C$ & 5) & 10.3 & 1.9 & 0.9 & 2.3 & 15.6 & 31.9 & 22.4 & 100.0 \\
\hline 31( & 6) & 14.2 & 2.0 & 0.4 & 2.6 & 19.3 & 21.6 & 25.0 & 100.0 \\
\hline $32 C$ & 7) & 17.3 & 0.9 & 1.1 & 3.8 & 23.3 & 13.2 & 27.9 & 100.0 \\
\hline $33 C$ & 8) & 20.4 & 1.3 & 1.7 & 4.5 & 28.1 & 6.6 & 18.6 & 100.0 \\
\hline 34( & 9) & 16.8 & 2.6 & 2.1 & 3.5 & 25.2 & 2.6 & 13.5 & 100.0 \\
\hline $35 C$ & 10) & 13.4 & 2.9 & 2.6 & 1.7 & 20.7 & 2.4 & 17.1 & 100.0 \\
\hline $36 c$ & 11) & 11.4 & 1.5 & 2.8 & 1.8 & 17.7 & 1.6 & 14.9 & 100.0 \\
\hline 37( & 12) & 14.9 & 2.1 & 2.8 & 2.1 & 22.0 & 1.9 & 11.0 & 100.0 \\
\hline $38 C$ & 13) & 9.7 & 1.4 & 3.6 & 1.2 & 16.2 & 5.9 & 16.7 & 100.0 \\
\hline $39 C$ & 14) & 11.2 & 1.4 & 3.5 & 1.3 & 17.5 & 2.7 & 15.4 & 100.0 \\
\hline
\end{tabular}

地のみである。これは，景気局面の好転に合せ安偳ざを武器に再進をはかったがそ の浸透状況が各地域により異なることによる。

1920年代半ばの各地域の状況を見てみよう。タイでは生金巾(生地綿布の一)につい ては，日本品が輸入品の大半を占めている(12)。もっともタイの輸入綡上は日本か らの輸入は1935年で $5.6 \%$ にかならない。タイへの輸入は香港，シンガポールを経 由するものが大部分であるからた。同年の生金巾輸入の $79.2 \%$ 占める香港，シンガ ポール仕出品の多くが日本品である(13)。またタイでは1920年代の中葉においてすで に晒金巾の分野でも日本品が70\%を占め，イギリスの30\%をはるかにひきはなしてい る(14)。これもまたタイの輸入統計上では主としてシンガポール仕出となる。このよ らな発展を見ながらタイの綿織物輸入に占める日本の比重が，総体として比較的小さ

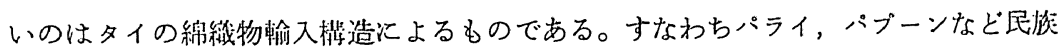
衣装用布(15)や，加工綿布(16)がかなりを占めており，その輸入はインド，イギリスが 
両大戦間期日本綿織物の東㓓フジア進出

第 3 表 続。同 (数量)

(千平方碑)

\begin{tabular}{|c|c|c|c|c|c|c|c|c|c|}
\hline & & 蒱 & フィリビン & 1 & 海 地 & $\begin{array}{l}4 \text { 地 域 } \\
\text { 小計 }\end{array}$ & 中 & イント & 锿 \\
\hline 1928 (S & 3) & 173,349 & 30,955 & 6,321 & 15,379 & 226,004 & 532,030 & 357,046 & $1,418,435$ \\
\hline 29( & 4) & 193,665 & 26,735 & 17,900 & 29,603 & 267,903 & 531,674 & 580,614 & $1,789,775$ \\
\hline $30 c$ & 5) & 182,756 & 35,064 & 16,056 & 44,583 & 278,459 & 436,401 & 403,835 & $1,571,401$ \\
\hline 31( & 6) & 212,498 & 33,556 & 5,786 & 41,345 & 293,185 & 239,323 & 403,936 & $1,412,071$ \\
\hline 32( & 7) & 352,296 & 21,409 & 24,397 & 82,226 & 480,328 & 202,419 & 644,458 & $2,032,719$ \\
\hline $33 c$ & 8) & 422,424 & 34,910 & 29,706 & 96,375 & 583,415 & 113,194 & 451,093 & $2,088,383$ \\
\hline 34( & 9) & 440,870 & 75,709 & 60,555 & 90,988 & 668,122 & 59,443 & 410,553 & $2,577,237$ \\
\hline 35( & 10) & 369,942 & 87,040 & 71,239 & 44,739 & 572,960 & 55,859 & 558,070 & $2,715,980$ \\
\hline 36( & 11) & 351,479 & 44,549 & 72,185 & 48,378 & 516,591 & 37,289 & 479,884 & $2,706,007$ \\
\hline 37( & 12) & 434,391 & 54,084 & 71,814 & 51,778 & 612,067 & 44,865 & 332,277 & $2,640,682$ \\
\hline 38( & 13) & 246,252 & 32,678 & 80,086 & 26,293 & 385,309 & 110,556 & 469,511 & $2,179,959$ \\
\hline $39 C$ & 14) & 368,670 & 36,923 & 83,055 & 29,453 & 518,101 & 22,924 & 474,461 & $2,443,629$ \\
\hline
\end{tabular}

(\%)

\begin{tabular}{|c|r|r|r|r|r|r|r|r|}
\hline $1928(\mathrm{~S} .3)$ & 12.2 & 2.1 & 0.4 & 1.0 & 15.9 & 37.5 & 25.1 & 100.0 \\
$29(\mathrm{4})$ & 10.8 & 1.4 & 1.0 & 1.6 & 14.9 & 29.7 & 32.4 & 100.0 \\
$30(\mathrm{5})$ & 11.6 & 2.2 & 1.0 & 2.8 & 17.7 & 27.7 & 25.6 & 100.0 \\
$31(\mathrm{6})$ & 15.0 & 2.3 & 0.4 & 2.9 & 20.7 & 16.9 & 28.6 & 100.0 \\
$32(\mathrm{7})$ & 17.3 & 1.0 & 1.2 & 4.0 & 23.6 & 9.9 & 31.7 & 100.0 \\
$33(\mathrm{8})$ & 20.2 & 1.6 & 1.4 & 4.6 & 27.9 & 5.4 & 21.6 & 100.0 \\
$34(\mathrm{9})$ & 17.1 & 2.9 & 2.3 & 3.5 & 25.9 & 2.3 & 15.9 & 100.0 \\
$35(\mathrm{10})$ & 13.6 & 3.2 & 2.6 & 1.6 & 21.0 & 2.0 & 20.5 & 100.0 \\
$36(\mathrm{11})$ & 12.9 & 1.6 & 2.6 & 1.7 & 19.0 & 1.3 & 17.7 & 100.0 \\
$37(\mathrm{1})$ & 16.4 & 2.0 & 2.7 & 1.9 & 23.1 & 1.6 & 12.5 & 100.0 \\
$38(\mathrm{13})$ & 11.2 & 1.4 & 3.6 & 1.2 & 17.6 & 5.0 & 21.5 & 100.0 \\
$39(\mathrm{14})$ & 15.0 & 1.5 & 3.3 & 1.2 & 21.2 & 0.9 & 19.4 & 100.0 \\
\hline
\end{tabular}

（資料）『紡聯月報』。1934年のみ『紡績事情参考書』からそれぞれ作製。

多くを占めているからである。晒綿布の 20 年代進出とパライ等特殊布を含む加工綿布 への進出の遅れ(17) という性格を持つタイに扣ける日本綿布進出は, 来るべき1930年 代の進出に扣いて特殊布を含さ加工綿布主導の進出となった。これは後に見る蘭領東 インドへの進出との相違を示すものである。フィリピンは，市場としてはタイより規 模は大きいkせよ，アメリカにより堅固にかためられて拉り，生地綿布でさえ1921年 に30\%強を占めたにすぎない(18)。

日本の東南アジア向け綿織物輸出の大部分を占める蘭領東インドでは，戦後の欧米 綿織物の復帰により1920年代を通じて英蘭日の3 国鼎立状態が続いている。生地綿布 の分野では1925年には75.3\%を日本製綿布が占め，他の地域と異なる特徵であるが， 1920年以降傾向的に比重を大きくする。しかしながら，蔄領東インド綿織物輸入中で 生地綿布の割合は傾向的に低下していくのみならず，企額絶対数上も急激に減少して いるので, 1920年代前半輸出総体としては減少傾向をたどる。1920年代後半この減少 
東南アジア一歷史と文化一 No. 11, 1982

をおぎなうの加工綿布で，その中軸を為したのが系染の縞三綾である。しかし1920 年代を通じて加工綿布総体としてはイギリス品が王倒的である。晒綿布ではオランダ 品が $60 \%$ 内外，イギリス品がその半分程度，両国品で輸入の大半を占めている。すな わち 3 国鼎立状態は，オランダ一晒，イギリス一加工，日本一生地といら形で成立し ている。蘭領東インドでは生地綿布に関する限り，第一次大戦後の後退は見られず， しかも進出市場としてはほぼ飽和状態であった。

これまで見たよらに，生地綿布を主軸とする限りに打いては，1920年代半ばに東南 アジア市場はほぼ飽和状態に達しており，かくして残された大市場としてのインドへ 集中的に日本の生地綿布は輸出される。これが他の地域は下降傾向にはいる1920年代 後半にインド市場での日本綿織物のピークが来る理由である。ちなみに，東南アジア 諸地域はいずれる輸入構成中に酔綿布の占める割合が大きく，生地綿布の市場が相対 的に小さいのに対し，インド市場は反対に生地綿布の比重が大きく25.9\%（1922年） を占めており，サリー用布のボーダー付生地綿布を加劣るならば，夷に52.0\%に造す る。中国市場の減少と東南アジア市場の飽和に直面した生地綿布にとって、インドの 生地綿布市場の大きさは魅力であった。

1920年代半ばの下降局面において，日本輸出綿布の直面した課題はほぼ次の四つで あった。

1. 製品の高度化

2. 流通機構の日本化

3. 運輸・倉庫の整備

4. 金融の充実

製品の高度化についてはこれまで述べてきたことで問題はなからら。インド，フィ リピン市場は未だ進出の可能性はあるものの，そこでは大きな抵抗が予測され，生地 綿布のこれ以上の発展は難しい。したがって，輸出綿䄉物の課題は日本がこれまであ

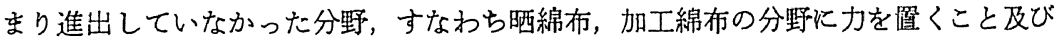
より細い禾を用いた高級品をつくることである。ここでは日本綿織物の安価さは機能 し得る。生地綿布のごとき飽和状態にあってはそれは十全には機能し得ない。しかし 問題は晒技術及び染色技術の発展にある。蘭領東インドの晒綿布，タイの加工綿布， ともに進出が難しいのはその点にあった。

流通機構の日本化は主として華僑の問題に係る。特に東南アジア向け輸出は，現地 の内国流通ばかりでなく，日本からの輸出にも係わっていた。投機や度重なる日促排

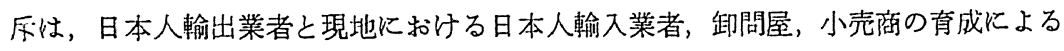


両大戦間期日本綿熾物の東南アジア進出 日本品流通ルートの願望となった(19)。これらの課題は1を除いては1930年代に至っ ても解決されたとは言い難い。しかし 1 の課題の解浹は，とにもかくにも1930年代の 発展の前提を用意したのである。

日本の綿工業が綿織物の加工に関心を持つようになったのは, やはり第一次大戦を 契機にしてのことであった。町工場の規模で行なわれていた漂白，染色工程が拡大し， 一方紡績資本がこの分野に進出してきた。早い例では1914年に富士瓦斯紡績が直営部 加工工場を設立し,中国向けの晒金巾の製造を始めた。その後鐘淵紡績が1918年に唒部 門を，1824年に捺染部門をとれぞれ同社淀川工場に設監したという例が見られる(20)。 1920年代に日本紡績資本は，紡績一織布の一貫生産から，紡繢一織布一加工の一貫生 産へと展開したのた。この㑯向はこの後も継続し, 次第に町工場を系列化し, 太平洋 戦争直前には晒工業の大部分と染色工業の30４0\%を系列化していた(21)。とはいえ， 1920年代は日本の織物加工の摇籃期であり, 加工綿布が東南アジア及びィンドで苦戦 をしいられていたのはこれまで見たと扤りである。晒を含む加工綿布の本格的進出は， この研究期間を経て1930年代まで待たなくてはならない。

\section{1930年代の䔵領東インド市場}

1929年に始まる世界恐慌は，東南アジア諸地域の購買力を大きく削った。日本の綿 布輸出も低下し, 新市場一一地域的にも品目的にも—が必要とされた。この不沉下 で1920年代の停滞の原因となった諸問題はいっそう切実なるのとなった。鐘濎紡績淀 川工場により蘭領東インド向け晒綿布の研究改良がなされ，十分オランダ品と対抗し 得る晒綿布の製作に成功したのは，1920年代から1930年代へと転換していく頃であっ た(22)。1931年の日本の金輸出再禁止後の為替下落は日本品を一層安価なものとし， 日本製綿織物はそれを引き金として新製品市場へと向っていった。

1930年代の日本の綿織物輸出は，かく乙て地域的新市場一西フジフ, アフリカ, 北中南米一之新製品晒，加工綿布による「新」市場という二つの戦略で展開した。 後者はこれから見るように一応の成功を見たが，前者はあまり成功したとは言い難い。 第 4 表は日本の輸出綿布の種類別推移を見たものである。晒綿布が生地綿布を抜くこ とがないにせよ，1930年代にはいり大きな位置を占めるようになったことがわかる。 こうした晒綿布と加工綿布の輸出增大を基盤に, 世界的不況の中にありながら1934年 には金額に特いても1929年ピークの水隼を抜く輸出額を達成するのである。

では地域的拡大はどうたったか。第 5 表はこれを見たるのである。第 5 表について は説明の必要があろう。通常日本の綿織物輸出についての旧市場は中国市場のことを 
東南アジア一歴史と文化一 No. 11, 1982

指すようである(23)。ここでは 1920 第 4 表 日本の輸出綿布種類別推移

年代までに一定の進出を見た満州, 関東州, 英領インド, 蘭領東インド の 4 地域を指している。中国市場は 1930年代にはいり急速に減少するの でこれを除外した。一見してわかる と㧍り，1930年代にはいって10\%ほ ど旧市場の占める割合は隇少するも のの低落傾向は見せていない。新市 場開拓の困難であったことがわかる。 しかしこれを品目別に見ると少しく 異なった像が浮び上ってくる。第 6 表から第 8 表は, 生地, 晒, 加工に 分類して表わしたものである。第 6 表から明らかなように, 生地綿布は 1920年代から1930年代にかけて旧市 場の割合が急速に下落している。こ のことは，旧市場の生地綿布受け容 れの力が限界に来ていたことを示し ている。地域的多角化が進んだので

\begin{tabular}{|c|c|c|c|c|c|}
\hline & & 生 地 & 晒 & 加 & 総 \\
\hline 1928 (S. & . 3) & 123,214 & 27,497 & 201,350 & 352,062 \\
\hline 29( & 4) & 157,804 & 29,648 & 225,014 & 412,468 \\
\hline 30( & 5) & 106,144 & 27,374 & 138,477 & 271,997 \\
\hline 31( & 6) & 68,242 & 25,664 & 104,666 & 198,573 \\
\hline 32( & 7) & 88,739 & 48,816 & 150,979 & 288,534 \\
\hline 33( & 8) & 93,235 & 78,027 & 211,623 & 382,885 \\
\hline 34( & 9) & 122,474 & 88,825 & 279,154 & 490,453 \\
\hline $35(1$ & 10) & 144,074 & 85,146 & 264,717 & 493,939 \\
\hline $36<1$ & 11) & 142,866 & 85,183 & 254,455 & 482,505 \\
\hline 37( & 12) & 148,433 & 124,276 & 299,743 & 572,453 \\
\hline 38( & 13) & 126,318 & 88,773 & 188,912 & 404,004 \\
\hline $39<1$ & 14) & 110,512 & 79,637 & 213,539 & 403,689 \\
\hline
\end{tabular}

同構成比

\begin{tabular}{|c|c|c|c|c|}
\hline 1928 (S. 3) & 34.9 & 7.8 & 57.1 & 100.0 \\
\hline 29( & 38.2 & 7.1 & 54.5 & 100.0 \\
\hline $30 \mathrm{C}$ & 39.0 & 10.0 & 50.9 & 100.0 \\
\hline 31( & 34.3 & 12.9 & 52.7 & 100.0 \\
\hline 32( & 30.7 & 16.9 & 52.3 & 100.0 \\
\hline 33( & 24.3 & 20.3 & 55.2 & 100.0 \\
\hline 34( & 24.9 & 18.1 & 56.9 & 100.0 \\
\hline $35(10)$ & 29.1 & 17.2 & 53.5 & 100.0 \\
\hline $36(11)$ & 29.6 & 17.6 & 52.7 & 100.0 \\
\hline $37(12)$ & 25.9 & 21.7 & 52.3 & 100.0 \\
\hline $38(13)$ & 31.2 & 21.9 & 46.7 & 100.0 \\
\hline 39( & 27.3 & 19.7 & 52.8 & 100.0 \\
\hline
\end{tabular}

(資料)『紡咯月報』より作笠。 ある。1929年，34年，37年とも英領インドが首位を占めているが，その比重は減退し ており，その分を旧市場の中では蘭領東インドが補っている。これについては，のち に蘭領東インドについて考察するときに詳しく述べることにする。生地綿布に比して 晒，加工綿布は旧市場の比率が注とんど一定である。晒綿布については1929年に扰い ても，中国，满州といら古い市場に実に59\%を依存していたことに注目したい。それ が1930年代にはいると蘭領東インド，英領インドを主軸とするようになり，輸出量も 飛躍的に增大することになる。また 1930 年代後半にアメリカ合咅国の比率が增加して いる。この結果つメリカとの間に綿布輸出をめぐっての経済摩擦が生じた。加工綿布 も，ほぼ晒綿布と同じ特徵を有している。

ここでインドが生地綿布で首位を占めるのに対し，晒，加工綿布は蘭領東インドが 首位を占めていることに着目しょう。1920年代に未だ進出の余地を残していたインド は，1929年にピークを遅れて迎えた。1930年代にはいって，徆，加工綿布を含め再度 
両大戦間期日本綿袢物の東南アジア進出

第 5 表 日本の綿布仕向地別推移

(千月)

\begin{tabular}{|c|c|c|c|c|c|c|}
\hline \multicolumn{3}{|c|}{1929} & \multicolumn{2}{|c|}{1934} & \multicolumn{2}{|c|}{1937} \\
\hline 1 & 英領インド & 108,953 & 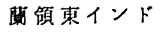 & 82,827 & 蔽領東インド & 85,602 \\
\hline 2 & 中 & 107,931 & 英領イント & 66,813 & 英 領 1 ン & 63,049 \\
\hline 3 & 蘭項東インド & 42,308 & 満 & 25,238 & 満 & 55,592 \\
\hline 4 & 満 & 41,485 & $=\dot{\forall}>1$ & 20,880 & フルビンチン & 29,297 \\
\hline 5 & 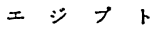 & 24,070 & 咸 東 州 & 10,989 & 期 東 & 28,991 \\
\hline 6 & 香 & 20,788 & フルぜンチン & 9,778 & $\begin{array}{l}\text { ケニア, ウガンダ } \\
\text { 及びタンガーニカ }\end{array}$ & 22,396 \\
\hline 7 & 閣 束 州 & 15,378 & オーストラリア & 8,946 & アメリカ合烐国 & 22,197 \\
\hline & & 412,468 & & 492,350 & & 572,453 \\
\hline & 上位 3 地域合計 & 259,192 & & 174,878 & & 204,243 \\
\hline & 旧市㘯合訫 & 208,124 & & 185,867 & & 233,234 \\
\hline
\end{tabular}

同搆成比

(\%)

\begin{tabular}{|c|c|c|c|c|c|c|}
\hline 1 & 英領イント & 26.4 & 蔽領東インド & 16.8 & 蔽頋東インド & 14.9 \\
\hline 2 & 中 & 26.1 & 英頒 インド & 13.5 & 英 領 インド & 11.0 \\
\hline 3 & 蔽領東インド & 10.2 & 満 & 5.1 & 满 & 9.7 \\
\hline 4 & 游 & 10.0 & $x \ddot{\prime}>r$ & 4.2 & アルゼンチン & 5.1 \\
\hline 5 & 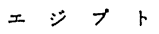 & 5.8 & 闺 束 州 & 2.2 & 関束 州 & 5.0 \\
\hline 6 & 番 & 5.0 & フルゼンチン & 1.9 & $\begin{array}{l}\text { ケニフ, ウガンタ } \\
\text { 及びタンカーニカ }\end{array}$ & 3.9 \\
\hline 7 & 関 束 州 & 3.7 & オーストラリア & 1.8 & アメリカ合绿国 & 3.8 \\
\hline & & 100.0 & & 100.0 & & 100.0 \\
\hline & 上位 3 地域合計 & 62.8 & & 35.5 & & 35.6 \\
\hline & 旧市场合計 & 50.4 & & 37.7 & & 40.7 \\
\hline
\end{tabular}

(資料) 1929，1937年は『紡聯月報』，1934年は『紡績事请参考書』よりそれぞれ作製。

（注）旧师場とは，ここでは英領インド，闌領東インド，溞州，関東州をさす。1929年 には未だ満州国は成立していないが，比較のため中国から分離した。

進出をはかると，1933年にはじをる日印会商により，インドからの綿花輸入にリンク して綿布輸出総量が決まり，乙かもその内訳が生地綿布 $45 \%$ ，ボーダー付生地綿布 13 \%，晒綿布 $8 \% ，$ 加工綿布34\%となった。1930年代にはいり，晒綿布輸出が主軸とな りつつあった日本としては，品種間の融通率に最後の望みをつないたが，それる小さ く押えられた(24)。この結果，注38 付表のごとく，1930年代に拈いても生地綿布が大 きな比重を占める古い型の輸出構成となったのである。さきにも述べたように,イン ドの綿織物輸入構成自体が生地綿布に大きな比重があったことも，この原因になって いることも忘れるべきではないであるう。

さて，これまで見たことから，1930年代の日本の綿織物輸出を代表するのは蘭領東 インド市場であるといってもよいであるう。以下，1930年代における蘭領東インド市 場への進出を考察しよう。何故蘭領東インドが日本綿織物の主要市場となったのかと いらことが，まず問題となる。第 1 には，東南フジア諸地域中では人口が多いという 
東南アジア一歷史と文化一 No. 11, 1982

第 6 表 日本の輸出綿布種類別仩向地別推移

$\mathrm{A}$ 生 地

(千平方码)

\begin{tabular}{|c|c|c|c|c|c|c|}
\hline \multicolumn{3}{|c|}{1929} & \multicolumn{2}{|c|}{19334} & \multicolumn{2}{|c|}{19937} \\
\hline 1 & 英領インド & 434,476 & 英領インド & 218,986 & 英領インド & 124,315 \\
\hline 2 & 澏 & 71,834 & 蔄領東インド & 78,035 & 閶領束インド & 106,430 \\
\hline 3 & $\simeq \ddot{\forall} \rightarrow r$ & 63,676 & $\simeq \ddot{\forall}>r \quad r$ & 61,813 & 楛 & 91,229 \\
\hline 4 & 蘭領東インド & 50,215 & 満 & 49,472 & $\begin{array}{l}\text { フングロ・エジブ } \\
\text { シフソスーダンース }\end{array}$ & 46,572 \\
\hline 5 & 中 & 45,332 & オーストラリ & 34,612 & 7 & 37,930 \\
\hline 6 & 咸 & 19,223 & 東 & 31,478 & 问 & 35,663 \\
\hline 7 & 香 & 18,193 & f & 21,743 & 中 & 29,355 \\
\hline & & 815,664 & & 772,495 & & 810,854 \\
\hline & 上位 3 地域合計 & 569,986 & & 358,834 & & 321,974 \\
\hline & 旧市场合計 & 575,748 & & 377,971 & & 357,637 \\
\hline
\end{tabular}

同構成比

(\%)

\begin{tabular}{|c|c|c|c|c|c|c|c|}
\hline 1 & 英领 インド & 53.2 & 英領 インド & 28.3 & \multirow{2}{*}{\multicolumn{2}{|c|}{$\begin{array}{l}\text { 英領イント } \\
\text { 領顷インド }\end{array}$}} & 15.3 \\
\hline 2 & 洲 州 & 8.8 & 藏領東インド & 10.1 & & & 13.1 \\
\hline 3 & 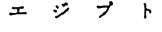 & 7.8 & エ $シ フ ゙ ト$ & 8.0 & \multicolumn{2}{|c|}{ 渶州 } & 11.2 \\
\hline 4 & 蘭領東インド & 6.1 & 满 & 6.4 & \multicolumn{2}{|c|}{$\begin{array}{l}\text { アンク゚ロ・エジブ } \\
\text { シフンスーダン }\end{array}$} & 5.7 \\
\hline 5 & 中 & 5.5 & オーストラリフ & 4.4 & $T \quad F$ & ข & 4.6 \\
\hline 6 & 咸 & 2.3 & 哭 & 4.0 & 来 & 州 & 4.3 \\
\hline 7 & 香 & 2.2 & f & 2.8 & 中 & 国 & 3.6 \\
\hline & 計 & 100.0 & & 100.0 & & & 100.0 \\
\hline & 上位 3 地域合計 & 69.8 & & 46.4 & & & 39.7 \\
\hline & 旧师聕合計 & 70.5 & & 48.9 & & & 44.1 \\
\hline
\end{tabular}

（資料・注）第 5 表に同 ( 8 麦まで)。

〈参考〉金額構成比

\begin{tabular}{|c|c|c|c|c|c|c|}
\hline 1 & 英領 インド & 47.9 & 英領インド & 24.5 & 潜 & 14.0 \\
\hline 2 & 州 & 10.5 & 㡀領東インド & 9.1 & 闌項 束インド & 12.4 \\
\hline 3 & $\simeq \forall>1$ & 9.1 & 州 & 8.2 & 英既 イ & 11.4 \\
\hline 4 & 中 & 6.3 & 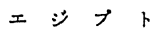 & 7.6 & 関 梌 州 & 5.4 \\
\hline 5 & 闌領東インド & 5.6 & オーストラリフ & 4.9 & & 4.5 \\
\hline 6 & 関 東 & 2.7 & 関 東 州 & 4.9 & $\begin{array}{l}\text { アソタ゚ロ・エジフ } \\
\text { シフンスーダソ }\end{array}$ & 4.5 \\
\hline 7 & 香 & 2.3 & f & 3.2 & オーストラリて & 4.3 \\
\hline & & 100.0 & & 100.0 & & 100.0 \\
\hline & 上位 3 地城合計 & 67.5 & & 42.0 & & 37.9 \\
\hline & 旧市場合計 & 66.8 & & 46.9 & & 43.3 \\
\hline
\end{tabular}

ことがあげられよう。蘭領東インドにはおよそ 6,000 万人の人間が住んでおり，その らちジャワ島だけで 4,000 万人がいる。仏領インドシナの 2,000 万人，タイ，ビルマ， フィリピンの 1,500 万人前後に比す時，その大きさは明らかである(25)。第 2 には， 豊富な一次産品による購買力である。ゴム, 石油, 砂糖, 錫, 茶, タハコ、コプラ, 
両大戦間期日本綿織物の東南アジア進出

第 7 表 日本の翰出綿布種類別仕向地別推移 続

B 晒

(千平方碼)

\begin{tabular}{|c|c|c|c|c|c|c|c|c|}
\hline \multicolumn{5}{|c|}{1929} & \multicolumn{2}{|c|}{1934} & \multicolumn{2}{|c|}{1937} \\
\hline 1 & 中 & & 国 & 57,385 & 蘭面禁イント & 98,803 & 間領束イント & 119,371 \\
\hline 2 & 㮱 & & 州 & 18,254 & 英嶺イント & 59,192 & フメリカ合㨀国 & 108,682 \\
\hline 3 & 英領 & イン & & 16,311 & 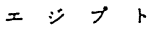 & 39,164 & 英領イント & 72,876 \\
\hline 4 & 闌領 & 東イソ & $F$ & 10,781 & 中 & 26,724 & 仏領モロッコ & 44,346 \\
\hline 5 & 番 & & 港 & 6,430 & ク & 21,878 & 闵 & 32,672 \\
\hline 6 & 阔 & 查 & 州 & 6,211 & 海峡㯕民地 & 20,369 & 1 & 25,210 \\
\hline 7 & $>1$ & リ ピ & ソ & 2,561 & フィリビン & 14,849 & 溚 & 24,540 \\
\hline & 総 & & 計 & 128,086 & & 524,643 & & 646,182 \\
\hline & 上位 & 地域合 & & 91,950 & & 197,159 & & 300,929 \\
\hline & 旧访 & 场 合 & 計 & 51,557 & & 179,328 & & 249,459 \\
\hline
\end{tabular}

同㩐成比

\begin{tabular}{|c|c|c|c|c|c|c|}
\hline 1 & 中 & 44.8 & 䎔領来インド & 18.8 & 闌領東インド & 18.4 \\
\hline 2 & 泚 & 14.2 & 英領インド & 11.2 & アメリカ合杵国 & 16.8 \\
\hline 3 & 英颃インド & 12.7 & エ $シ \quad フ 十$ & 7,4 & 英領インド & 11.2 \\
\hline 4 & 政篗インド & 8.4 & 国 & 5.0 & 仏領モロッこ & 6.8 \\
\hline 5 & 香 & 5.0 & タ & 4.1 & 唊 東 州 & 5.0 \\
\hline 6 & 関東 & 4.8 & 海映植民地 & 3.8 & タ & 3.9 \\
\hline 7 & フィリビン & 1.9 & フィリビン & 2.8 & 州 & 3.7 \\
\hline & & 100.0 & & 100.0 & & 100.0 \\
\hline & .七位 3 地域合計 & 71.9 & & 37.5 & & 46.5 \\
\hline & 旧市场合計 & 40.2 & & 34.1 & & 38.6 \\
\hline
\end{tabular}

パームオイル, コーヒー,キナ等々。これらの輸出により蘭領東インドの貿易収支は 毎年黑字を続けていた。第 3 には，宗主国オランダが自由貿易政策を堅持していたこ と。蘭領東インドの輸出品は本国オランダの需要や工業と結びついていなかった。ゴ ムの丰に70\%は直接あるいはシンガポールを経由してアメリカに送られた。砂糖の40 \%はインドに，茶の $50 \%$ はイギリスに，パームオイルの60\%はアメリカに直接輸出さ れた。一旦本国に送られ然る後各国に輸出されるのは，タバュとキナなど少数である。 また一方，オランダの工業力は蘭領東インドの需要を十分まかなうるのではなかった。 かくしてオランダは，自由貿易主義をとり蘭領東インド市場を各国に開放する代りに 蘭領東インドの物産を買ってもらい利益を得ていた。第 4 には，蘭領東インドはイン ドのような高関税を課すことができなかった。これは19世紀にイギリスとオランダと の間に関税に関する協定が結ばれ，関税の限度が決められていたからである。通商条 約が結ばれ最恵国待遇を受けている限りに打いては日本品に高関税をかけるわけには いかなかった(26)。第 5 には，宗主国オラングの工業力が小さいこと。これはインド のイギリス,フィリピンのアメリカと決定的な差がある。 
東南アジアー歴史と文化一 No. 11, 1982

第 8 表 日本の輸出綿布種類別仕向地別推移 続

C 加 工

(千平方砸)

\begin{tabular}{|c|c|c|c|c|c|c|}
\hline \multicolumn{3}{|c|}{1929} & \multicolumn{2}{|c|}{1934} & \multicolumn{2}{|c|}{1937} \\
\hline 1 & 中 & 270,733 & 闌領東インド & 264,032 & 闌領東インド & 434,391 \\
\hline 2 & 蘭領東インド & 132,668 & エ $\because>゙$ & 132,709 & 英領 インド & 332,277 \\
\hline 3 & 英領 インド & 129,826 & 英領 インド & 132,375 & 淈 & 211,811 \\
\hline 4 & 齘 & 65,930 & 満 & 109,429 & アルゼンチン & 131,023 \\
\hline 5 & 香 & 60,069 & 海峡植民地 & 60,276 & アメリカ合望国 & 123,850 \\
\hline 6 & 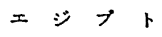 & 41,351 & フィリピン & 54,191 & 成東 州 & 115,173 \\
\hline 7 & 関 東 & 31,141 & 凰 & 42,247 & $\begin{array}{l}\text { ケニヤ、官ガンダ } \\
\text { 及びタガーニガ }\end{array}$ & 102,554 \\
\hline & 総 & 846,023 & & $1,294,948$ & & $2,640,682$ \\
\hline & 上位 3 地城合部 & 533,227 & & 529,116 & & 978,479 \\
\hline & 旧市坫合計 & 359,565 & & 548,083 & & $1,093,562$ \\
\hline
\end{tabular}

同棈成比

(\%)

\begin{tabular}{|c|c|c|c|c|c|c|}
\hline 1 & 国 & 32.0 & 蔽項 東インド & 20.3 & 蘭領來インド & 16.4 \\
\hline 2 & 領東インド & 15.6 & 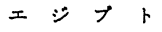 & 10.2 & 英領 イント & 12.5 \\
\hline 3 & 英領インド & 15.3 & 英領 インド & 10.2 & & 8.0 \\
\hline 4 & 州 & 7.7 & 满 & 8.4 & フルセンチン & 4.9 \\
\hline 5 & 港 & 7.1 & 海峡租民地 & 4.6 & アメリカ合觔国 & 4.6 \\
\hline 6 & $x \quad \forall>゚ ト$ & 4.8 & フィリビン & 4.1 & 関 東 州 & 4.3 \\
\hline 7 & 関 東 州 & 3.6 & 東 州 & 3.2 & $\begin{array}{l}\text { ケニフ、ウガンダ } \\
\text { 及びンガーニガ }\end{array}$ & 3.8 \\
\hline & 総 & 100.0 & & 100.0 & & 100.0 \\
\hline & 上位 3 地域合計 & 63.0 & & 40.8 & & 37.0 \\
\hline & 旧市苓合㖕 & 42.5 & & 42.3 & & 41.4 \\
\hline
\end{tabular}

しかし，1930年代の日本の綿織物輸出の急增にとって大きな要因となったのは，阇 領東インドの輸入綿布中に占める晒綿布の比率が高かったことである。さきに見たご とく，東南アジア諸国はインドに比して晒綿布の比率が大きい。中でも蘭領東インド はその30\%が晒綿布であった(第 9 表)。では何故晒綿布の需要が大さかったのであ ろらか。それは晒綿布がバティク(ジャワ更紗) の原料用布であったからであった。 この蘭領東インドの古くからの䗨縝染に対する伝統的指向は，加工綿布に対する需要 を引き下げ，その分晒綿布の需要を增加させた。古くは貴族の女達の手芸品であった バティクであるが，型による徖押式が作られるよらになってから発達し，工場に打い て大量に生産するようになってきた。1930年には工場数は，西部シャワ1，829，中部 ジャワ2,347, 東部ジャワ280, この合計4,456で, 労働者は約 1 万7,000人であった(27)。 平均して 1 工場当り 4 人弱の小規模であるが，この他にも問屋制家内工業的形態のも のもあるからかなりの発展をみていた。

バティク用布の大半は，晒綿布のらちキャンブリックと呼ばれる旿金巾の高級品で， 
両大戦間期日本綿織物の東南フジフ僬紫

第 9 表 蘭頒東イソド綿布翰入額

(千ギルダー)

\begin{tabular}{|c|c|c|c|c|c|}
\hline & 生地穆布 & 的布 & サロン顠 & その他綿布 & 合 \\
\hline $1920(T, 9)$ & 48,699 & 101,529 & 30,769 & 134,758 & 315,755 \\
\hline $21(10)$ & 26,818 & 70,551 & 28,079 & 84,454 & 209,902 \\
\hline $22(11)$ & 18,960 & 61,280 & 17,108 & 60,780 & 158,128 \\
\hline $23(12)$ & 15,154 & 55,615 & 16,470 & 60,647 & 147,886 \\
\hline $25(14)$ & 16,650 & 58,578 & 11,651 & 68,219 & 155,098 \\
\hline $26(S .1)$ & 12,177 & 39,657 & 10,139 & 75,075 & 137,048 \\
\hline 27( & 11,322 & 38,225 & 10,153 & 86,285 & 145,985 \\
\hline 29( & 13,203 & 50,141 & 15,657 & 93,842 & 172,843 \\
\hline 30( & 9,981 & 38,745 & 11,149 & 63,393 & 123,268 \\
\hline 31( & 8,289 & 26,449 & 8,302 & 46,062 & 89,102 \\
\hline 32( & 7,364 & 21,342 & 7,588 & 36,865 & 73,159 \\
\hline 33( & 5,932 & 20,924 & 6,965 & 29,619 & 63,440 \\
\hline
\end{tabular}

同潇成比

\begin{tabular}{|r|r|r|r|r|r|}
\hline 1920 (T. 9) & 15.4 & 32.2 & 9.7 & 42.7 & 100.0 \\
$21(10)$ & 12.8 & 33.6 & 13.4 & 40.2 & 100.0 \\
$22(11)$ & 12.0 & 38.8 & 10.8 & 38.4 & 100.0 \\
$23(12)$ & 10.2 & 37.6 & 11.1 & 41.0 & 100.0 \\
$25(14)$ & 10.7 & 37.8 & 7.5 & 44.0 & 100.0 \\
26 (S. 1) & 8.9 & 28.9 & 7.4 & 54.8 & 100.0 \\
$27(52)$ & 7.8 & 26.2 & 7.0 & 59.1 & 100.0 \\
$29(4)$ & 7.6 & 29.0 & 9.1 & 54.3 & 100.0 \\
$30(5)$ & 8.1 & 31.4 & 9.0 & 51.4 & 100.0 \\
$31(5)$ & 9.3 & 29.7 & 9.3 & 51.7 & 100.0 \\
$32(5)$ & 10.1 & 29.2 & 10.4 & 50.4 & 100.0 \\
$33(5)$ & 9.4 & 33.0 & 11.0 & 46.7 & 100.0 \\
\hline
\end{tabular}

（注）1920２3年は『海外市场に旋故る本邦綿布』

1925年 は『爪哇に榆入さるる䄸布に就て』

1926〜27年は『本邦輪出綿紋物の現倩』

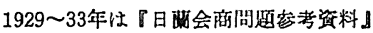

よりそれぞれ作犁。但し1925〜27年はジャワ・マズラのみ。

キャンブリックは蘭領東インドの晒綿布輸入のほほ70\%前後を占めていた。1920年代 を経て細系，晒加工布の輸出へと進みつつあった日本にとってこの市場はうってつけ の大市場であった。しかし，1920年代にあってはキャンブリックはオランダ綿菜資本 の重要な分野であり，イギリス品さえもそれに大きく水をあけられ，第 2 位を確保す

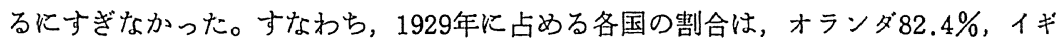
リス $13.8 \%$ ，日本 $3.6 \%$ あっあた。この伝統産業にあっては，糊付け仕上げに産地ご とに極めて保守的嘴好が存在したことが一つの原因であっだ。イギリスでさえこれに 㐫ずるのを徒労としてか，オランダに綿布を輸出し，仕上加工をして䕡領東インド 再輸出するという方法をとらざるを得なかったともいう(28)(29)。日本もかなり苦心を したようであるが，ささにのべた鐘紡をはじめ，ようやくオランダ品に対抗し得るキ 
東南アジア一歷史と文化一 No.11. 1982

第10表 蘭領東インド向け日本綿布種類別推移

(ジャワ・マズラ)

(千ギルダー)

\begin{tabular}{|c|c|c|c|c|c|}
\hline & 生地䄸布 & 西䄸布 & サロン類 & その他䄸布 & 合 \\
\hline 1920 (T. 9) & 22,740 & 9,179 & 168 & 26,980 & 59,067 \\
\hline $21(10)$ & 15,795 & 3,738 & 45 & 10,833 & 30,411 \\
\hline $22(11)$ & 10,402 & 1,353 & 6 & 10,299 & 22,060 \\
\hline $23(12)$ & 7,624 & 1,047 & - & 10,748 & 19,419 \\
\hline $24(13)$ & 11,450 & 1,791 & 一 & 18,064 & 31,305 \\
\hline $25(14)$ & 12,532 & 2,332 & - & 23,434 & 38,298 \\
\hline $26(S .1)$ & 9,709 & 730 & - & 25,446 & 35,885 \\
\hline 27( & 8.778 & 782 & 1 & 30,397 & 39,958 \\
\hline 28( & 8,571 & 1,347 & 19 & 29,066 & 39,003 \\
\hline $29 C$ & 8,485 & 2,369 & 1 & 35,958 & 46,813 \\
\hline $30 \mathrm{C}$ & 7,217 & 2,768 & 51 & 23,162 & 33,198 \\
\hline 31( & 6,175 & 3,775 & 261 & 21,676 & 31,887 \\
\hline 32( & 5,975 & 6,891 & 1,606 & 17,515 & 31,987 \\
\hline 33( & 4,767 & 14,259 & 3,646 & 16,612 & 39,284 \\
\hline 34( & 6,081 & 9,484 & 1,869 & 18,250 & 35,684 \\
\hline $35(10)$ & 5,438 & 5,244 & * & 14,493 & $\Delta$ \\
\hline 36( & 6,818 & 5,361 & * & 11,204 & $\triangle$ \\
\hline
\end{tabular}

同構成比

\begin{tabular}{|c|c|c|c|c|c|}
\hline $1920(\mathrm{~T} .9)$ & 38.5 & 15.5 & 0.3 & 45.7 & 100.0 \\
\hline $21(10)$ & 51.9 & 12.3 & 0.1 & 35.6 & 100.0 \\
\hline $22(11)$ & 47.2 & 6.1 & 0.0 & 46.7 & 100.0 \\
\hline $23(12)$ & 39.3 & 5.4 & - & 55.3 & 100.0 \\
\hline $24(13)$ & 36.6 & 5.7 & - & 57.7 & 100.0 \\
\hline $25(14)$ & 32.7 & 6.1 & - & 61.9 & 100.0 \\
\hline $26(S .1)$ & 27.1 & 2.0 & - & 70.9 & 100.0 \\
\hline 27( & 22.0 & 2.0 & 0.0 & 76.1 & 100.0 \\
\hline 28( & 22.0 & 3.5 & 0.0 & 74.5 & 100.0 \\
\hline $29 \mathrm{C}$ & 18.1 & 5.1 & 0.0 & 76.8 & 100.0 \\
\hline $30 \mathrm{C}$ & 21.7 & 8.3 & 0.2 & 69.8 & 100.0 \\
\hline 31( & 19.4 & 11.8 & 0.8 & 68.0 & 100.0 \\
\hline $32 C$ & 18.7 & 21.5 & 5.0 & 54.8 & 100.0 \\
\hline $33 \mathrm{C}$ & 12.1 & 36.3 & 9.3 & 42.3 & 100.0 \\
\hline $34(9)$ & 17.0 & 26.6 & 5.2 & 51.1 & 100.0 \\
\hline
\end{tabular}

（注）1920 24年は「海外市场に旋ける木邦線布」

1925年は8爪哇に輸入さるる綿布に就て』

1926〜27年は『木邦輸出綿峨物の現敬】

1928 29年は『南洋䄸布市垛梘察記』

1930 36年は「日藏留易参考筑料」

但し1930〜36年のサロン類については『闌印市场に於ける朴那絊有』よりそ

れぞれ作製した。

+ソブリックの製作に成功したのである。

かくして1930年代の日本綿織物は，晒綿布を主軸として蘭領東インドへ流入してい く。第10表にも明らかなように，1932年には生地綿布を抜いている。日本の綿織物輸 
両大戦間期日本綿織物の東南アジア造然

出が晒，加工にシフトしていく時期 にあって，蘭領東インド市場が果し た重要な役割はここにある。くり返 して言らが，1930年代の日本綿布の 大量な進出を実現した主要因は円為 替下落による価格の低下であるらが, それを可能にしたのは日本輸出綿布 の晒，加工布への高度化であり，市 場的には，1920年代に生地綿布市場 として掌中のものとした蘭領東イン ド市場の存在であった。

1933年の蘭領東インド向け日本綿 織物のピーク(30)は，こうして晒綿 布の進出により達成された。第11表に見るように，1932年には日本の比染は $41.1 \%$ と なり，オランダと晒綿布を分けあう形になり，翌33年には奏に $82.1 \%$ 大部分を日本 品とした。ここに至って，オランダは高級キャンブリックでのみ優位を保つにすぎな くなった。そのため遂に1934年 2 月28日，蘭領東インド政庁は非常時晒織物輸入制限 令を発令し日本品の流入を阻止しょうとした。しかし，この法令が一応の成功を見た ものの，晒綿布の分野でオランダの昔日の勢力を回復するものとはならなかったのは， 第11表で明らかなと拉りである。

ここで生地綿布の分野に一応目を向けておこう。第12表によれば1934年に再び上昇 に転じる。これは契は晒綿布の輸入制限により，バティク用布の生地綿布での代替が 生ずることになるからである。生地綿布を用いたバティクは，西ジャワでは以前から 見られたが，主流は晒綿布であった。ことの意外な成行きに驚いた闌領東インド政庁 は，日闌会商の最中の1933年 6 月に生地綿布の輸入制限令を発令しようとするが，こ れは日本側の蘭領東インド向け生地綿布積出㭼止といら強行策により一旦は引込めら れた。しかし，会商決裂後の装35年 1 月21日再度輸入制限令が発せられ，生地綿布輸 入にゆるい制限が加えられた。

罠後に加工綿布について簡単に述べておこ5(31)。1920年代の日本織物の 加工綿布 での主力商品は，蘭領東インド市場においては，系染綿布である 縞三綾であった。

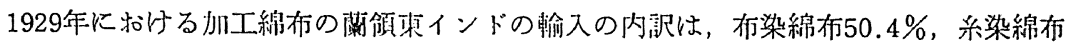
$25.9 \%$ ，捺染綿布 $23.6 \%$ であった。同年の糸染綿布に占める日本品の割合は $74.0 \%$ で 
東南フジア一歷史と文化一 No. 11，1982

第11表 晒綿布仕出国別翰入数量及額 (ジャワ・マズラ)

$\mathrm{A}$ 数 量 (千ャード)

\begin{tabular}{|c|c|c|c|c|}
\hline & 日本 & オランダ & イギリス & 総 計 \\
\hline $1929(\mathrm{~S} .4)$ & 9,089 & 115,459 & 37,786 & 164,320 \\
\hline 30( & 11,896 & 101,685 & 23,414 & 138,689 \\
\hline 31( & 19,715 & 83,434 & 12,130 & 116,532 \\
\hline 32( & 48,687 & 58,634 & 10,077 & 118,392 \\
\hline $33 C$ & 113,978 & 18,493 & 5,448 & 138,873 \\
\hline 34( & 81,868 & 35,080 & 3,814 & 122,079 \\
\hline $35(10)$ & 48,066 & 49,051 & 3,347 & 101,845 \\
\hline $36(11)$ & 50,842 & 47,232 & 4,241 & 102,543 \\
\hline
\end{tabular}

同構成比

\begin{tabular}{|c|c|c|c|c|}
\hline $1929(\mathrm{~S} .4)$ & 5.5 & 70.3 & 23.0 & 100.0 \\
\hline $30 C$ & 8.6 & 73.3 & 16.9 & 100.0 \\
\hline 31( & 16.9 & 71.6 & 10.4 & 100.0 \\
\hline 32( & 41.1 & 49.5 & 8.5 & 100.0 \\
\hline 33( & 82.1 & 13.3 & 3.9 & 100.0 \\
\hline 34( & 67.1 & 29.3 & 3.1 & 100.0 \\
\hline $35(10)$ & 47.2 & 48.2 & 3.3 & 100.0 \\
\hline $36(11)$ & 49.6 & 46.1 & 4.1 & 100.0 \\
\hline
\end{tabular}

$B$ 金 額

\begin{tabular}{|c|c|c|c|c|}
\hline 1929 (S. 4 & 2,369 & 29,560 & 10,302 & 42,915 \\
\hline 30( & 2,768 & 23,577 & 6,213 & 33,107 \\
\hline 31( & 3,774 & 15,754 & 2,876 & 22,714 \\
\hline 32( & 6,890 & 9,138 & 1,845 & 18,047 \\
\hline 33( & 14,260 & 2,670 & 1,074 & 18,195 \\
\hline 34( & 9,484 & 4,606 & 724 & 15,001 \\
\hline 35( & 5,244 & 5,851 & 618 & 11,932 \\
\hline 36( & 5,361 & 5,455 & 692 & 11,557 \\
\hline
\end{tabular}

同满成比

\begin{tabular}{|c|c|c|c|c|}
\hline 1929 (S. 4 & 5.5 & 68.9 & 24.0 & 100.0 \\
\hline $30 \mathrm{C}$ & 8.4 & 71.2 & 18.8 & 100.0 \\
\hline 31( & 16.6 & 69.4 & 12.7 & 100.0 \\
\hline 32( & 38.2 & 50.6 & 10.2 & 100.0 \\
\hline $33 c$ & 78.4 & 14.6 & 5.9 & 100.0 \\
\hline 34( & 63.2 & 30.7 & 4.8 & 100.0 \\
\hline $35(\quad 10$ & 43.9 & 49.0 & 5.2 & 100.0 \\
\hline $36(11$ & 46.4 & 47.2 & 6.0 & 100.0 \\
\hline
\end{tabular}

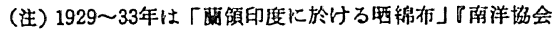
雑誌」第20巻第 5 号 1934 36年は「日闌留易育考资料」 上り作笠。
あり，稿三綾の独擅場であった。し かし，縞三続は生産が過剩となり， そのため価格引き下げの過当競争か ら品質の低下と，当時この流通を握 っていたブローカーの投機対象とな り墓穴を掘ることになった。代わっ て1930年代には捺染縞が輸出される よらになった。一方，縞綿布での経 験は稿サロンの輸出に生かされた。 1929年に日本品は布染綿布で $43.3 \%$ ， 挎染綿布で $44.1 \%$ \%あったのが， 1933年にはそれぞれ72.3\%，85.7\% を占めるよらになった。1930年代に 新規参入した縞サロンの分野では, 1933年には日本品が輸入の98.8\%を 占めるに至った。1934年 2 月13日， 綿織物の輸入制限の先頭を切ってサ ロン，輸入制限が出たのは当然であ った。

1920年代の日本の輸出綿布の課題 のIは，蘭領東インド市場に批いて はこのように解決されたものの，2 以下はどうであったろらか。流通の 日本化の動きは1920年代初頭にさか のぼる。蘭領東インドは東南アジフ に打いて在地の邦人商人の多い地域 である。第一次大戦を契機とした南 洋ブームの中, 蘭領東インドは大 小の邦人輸入商社, 小売商が矮生し た。しかし，1920年戦後恐慌を境に 整理段階にはいった。たがてれとは 反対に，日本の綿関係商社は闌領東 
両大戦間期日本綿織物の東南フジア造毞

インドに支店を設置しはじ める。1920年三井物産から 分れて東洋棉花が設立され ると、スラバヤに出張員， スマランに派出員が置かれ， 翌21年にはスラバヤが支店 に昇格，バタビアに派出員 が置かれた(32)。日本綿花 はとれに先立ち1919年スラ バヤに南洋出張所を置いて おり，1920年にはスマラン に出張員を瞋き，1921年に はスラパヤが支店に昇格， 24年にはバタビア，チェリ ボンに出張員を置いてい る(33)。

これら日本の大手商社は 整理期にあった邦人輸入商, 小売商を組織系列化乙，日 本の綿織物の販路拡大をは かららとした。例えば，日 本綿花は中村商店, 南洋商 会, 明治商会, 日布洋行を その系列下に㯰いた(34)。 しかし，この方法は綿布と して各地に売り別かれる場 合には幾分か效果を果した かもしれないが，1930年代 に入ると矛盾を生じること になる。つまり，晒綿布に 主力が渻かれることになる と, バティク用布を扱ら商
第12表 生地綿布仕出国別翰入額

$$
\text { (ジャワ・マズラ) }
$$

\begin{tabular}{|c|c|c|c|c|c|}
\hline & 日本 & オランダ & イギリス & 中 目 & 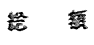 \\
\hline $1916(T .5)$ & 96 & 2,633 & 4,305 & & 7,807 \\
\hline $20(9)$ & 22,740 & 4,897 & 12,297 & & 41,135 \\
\hline $21(10)$ & 15,795 & 2,901 & 3,319 & & 22.877 \\
\hline $22(11)$ & 10,402 & 2,662 & 3,341 & & 16,616 \\
\hline $23(12)$ & 7,624 & 2,144 & 2,517 & & 12,606 \\
\hline $24(13)$ & 11,450 & 933 & 2,174 & & 15,576 \\
\hline $25(14)$ & 12,532 & 1,122 & 2,121 & & 16,650 \\
\hline $26(\mathrm{~S} .1)$ & 9,709 & 1,005 & 581 & 859 & 12,177 \\
\hline $27 C$ & 8,778 & 471 & 811 & 1,250 & 11,322 \\
\hline 29( & 8,485 & 456 & 606 & 1,318 & 10,880 \\
\hline $30 \mathrm{C}$ & 7,217 & 211 & 253 & 795 & 8,483 \\
\hline $31 \mathrm{C}$ & 6,175 & 237 & 76 & 599 & 7,095 \\
\hline 32( & 5,975 & 39 & 66 & 264 & 6,366 \\
\hline 33( & 4,767 & 11 & 26 & 278 & 5,114 \\
\hline $34 \mathrm{C}$ & 6,081 & 19 & 11 & 241 & 6,394 \\
\hline $35(10)$ & 5,438 & 10 & 19 & 24 & 5,534 \\
\hline $36(11)$ & 6,818 & 5 & 14 & 46 & 7,140 \\
\hline
\end{tabular}

同構成比

\begin{tabular}{|c|c|c|c|c|c|}
\hline $1916(T .5)$ & 1.2 & 33.7 & 55.1 & & 100.0 \\
\hline $20(9)$ & 55.3 & 11.9 & 29.9 & & 100.0 \\
\hline $21(10)$ & 69.0 & 12.7 & 14.5 & & 100.0 \\
\hline $22(11)$ & 62.6 & 16.0 & 20.1 & & 100.0 \\
\hline $23(12)$ & 60.5 & 17.0 & 20.0 & & 100.0 \\
\hline $24(13)$ & 73.5 & 6.0 & 14.0 & & 100.0 \\
\hline $25(14)$ & 75.3 & 6.7 & 12.7 & & 100.0 \\
\hline $26(S, 1)$ & 79.7 & 8.3 & 4.0 & 7.1 & 100.0 \\
\hline 27( & 77.6 & 4.3 & 7.2 & 11.0 & 100.0 \\
\hline 28( & 73.4 & 5.1 & 5.7 & 15.4 & 100.0 \\
\hline 296 & 78.0 & 4.2 & 5.6 & 12.1 & 100.0 \\
\hline $30<$ & 85.1 & 2.5 & 3.0 & 9.4 & 100.0 \\
\hline 316 & 87.0 & 3.3 & 1.1 & 8.4 & 100.0 \\
\hline 326 & 93.9 & 0.6 & 1.0 & 4.1 & 100.0 \\
\hline $33 c$ & 93.2 & 0.2 & 0.5 & 5.4 & 100.0 \\
\hline $34<$ & 95.1 & 0.3 & 0.2 & 3.8 & 100.0 \\
\hline $35 c$ & 98.3 & 0.2 & 0.3 & 0.4 & 100.0 \\
\hline $36(11)$ & 95.5 & 0.1 & 0.2 & 0.6 & 100.0 \\
\hline
\end{tabular}

（注）1916年 は『南洋織物事情』 1920～24年は『海外市場に於ける本邦綿布』 1925年は『爪姓に輸入さるる綿布に就て』 1926〜27年は『本邦翰出綿織物の現㓶』 1928～29年は『南洋綿布市場視察記』 1930～36年は『日關貿易参洘資料』 よりそれぞれ作製。 
東南アジア一歷史と文化一 No. 11, 1982

人は華僑の独㗐場であるため，対華僑商売の比重がいやが上にも高くならざるを得な いことになる(35)。このバティク産業と結びついた華僑の力は絶大で，扣いそれと邦 人商人のはいれるところではなかった。したがって流通の日本化は，1930年代にあっ ては絶望的となる(36)。

\section{4.むすびにか壳て}

本稿は，1920年代と1930年代の日本輸出綿織物の性格の相逢を明らかにし，1930年 代に蘭領東インド市場が戦略的に重要市場となることを明らかにしたつもりである。 かくて，日本綿業資本にとって蘭領東インド市場を制するか否かは死活問題となる。 一方，最後の市場である晒綿布市場を侵犯されたオランダ綿業資本と，その背後にあ るイギリス綿業資本にとっても重大な問題である。蘭領東インドが門戸開放をしてい るだけにその闘いは嬂烈なものとならざるを得ない。この結果として，1934年の輸入 割当とライセンス制を併用した輸入制限が出され，日蘭会商がバタビアで開かれた。 日蘭会商は，その年の12月一旦決裂するが，元々交渉を実りあるものにしようと双方 が考劣ていたか疑しい節もある(37)。

輸入制限は日本の綿織物の輸入を減少させ，オランダの市場回復を一定程度成功さ せたが，1930年代後半，世界恐慌から立直り景気が回復の徵を見せると再び日本綿䄉 物の翰出が増加し，1937年のピークを迎える(38)。このピークがこれまで述べた1930 年代的性格のものであることは言うまでもない。

日本の綿織物輸出の急増と輸入制限は，興味深い三つの現象を生んだ。第 1 は，㩧 領東インドにおける織布業の急速な展開である(39)。蘭領東インドの工業化はこれま でも努力されてきたものであり，特に綿業については種々の施策がなされてきた。し かし宗主国オランダとの関係もあり実現には困難がつきまとった。日本の綿製品の急 速な進出はオランダ資本に危機感をいたかせ，その闌領東インドへの工業投資を引き 出した。また華僑資本，アラビア人資本，インドネシア人資本の䄉物業も簇生せしめ た。第 2 には，輸入制限と織布業の展開が日本の綿糸及び人絹糸の輸出を増大させた ことである。特に人綟糸は，1937年に蘭領東インド向け輸出が $5.7 \%$ (第 4 位) を占 め，人綟織物輸出と合せ，勃興期にあった人綟産業の発展に貢献した(40)。第 3 は, 晒綿布の輸入制限によるバティク産業の不振である。このため，1936年キャンブリッ ク補償法を出し，補助金によって原料布の輸入制限による值上りを埋め合せようとし た(41)。

日本と東南アジア，蘭領東インドとの経済関係の研究は全くといってよい程ない。 
両大戦間期日本綿織物の東南アジフ造出

日本の経済進出と現地での摩擦の好例であるにもかかわらず。本稿はその準備のため の試論である(42)。

（連絡先 干185 国分寺市富士本 1-2-12）

注

1 日印会商についての最近の研究としては,

石井修 1980.「日印会商1933～34年一一戦前期日本経済外交の一画期—」『アシ フ経済』21-3 (1980．3). pp. 58-70.

柳沢悠 1980.「第一次日印会商（1933～34年）をめぐる英印関係」『経済と貿易』 129. pp. 30-47.

を参照。

2 戦前期の日本と桨南アジアとの経済関係についての論文は極めて少ない。本稿は 戦前期の綿織物輸出を圾ったものであるが，同時期日本の鉄鉣石輸入に大きな比重 を占めるに至ったマレーの鉄鉙石輸入を扱ったものに次のものがある。

安場保吉 1980. 「石原廎一郎と資源確保論」『東南アジア研究』18-3. pp. 120-131. 3フィリピン, 仏領インドシナ, 䍘領東インドについては, 南洋協会編 1943.『南 方圈貿易統計表』日本評論社。タイについては, 三菱経済研究所編 1933 .『東洋 及び南洋諸国の国際貿易と日本の地位』三菱経済研究所。但し，タイは1930 31年 度の数字から算出。英領マレーはシンガポールを含むため移出入が多く比較の対象 となりにくいので除外した。

4 フィリピンではこの時期アメリカからの輸入比率が一層增大し，むしろ30年代後 半に日本の比率は増加する。例えば1937年は $6.6 \%$ となる。

5 『紡績事情参考書』よりとった後出第 2 表の数字。ここでは東南フジフは便宜上 4 地域, 蘭領東インド, フィリピン, タイ, 海峡植民地と考えた。

6 ここの数字は前出南洋協会編『南方圈貿易統計表』海峡植民地を含さ。

7 フィリピンのみ1934年の数字。

8 正田健一郎 1978. 「戦前期・日本資本主義と東南アジア」正田健一郎編『近代 日本の東南アジフ観』アジア経済研究所所収。桜谷勝美 1978. 「貿易構造の変化 と国際収支」山崎隆三編『两大戦間期の日本資本主義』大月書店所収。ともに两大 戦間期の，日本と東南アジアの貿易関係のこの欠落をうめることを試みている。特 に後者は本稿のとりあげる綿織物についての言及があるが，論文構成上留易数字の

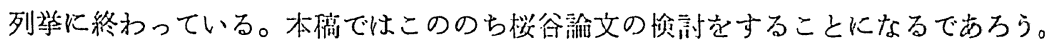

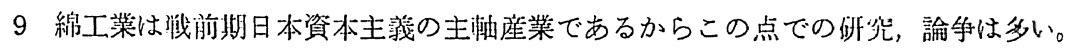


東南アジアー歷史と文化一 No. 11， 1982

貿易史に関する限りで筆者が参考にしたのは主として次の文献である。 中西市郎 1968.「『金輸出再禁止』以後の貿易・為替問題」『日本資本主義発達史 諭 III日本評論社所収。

林健久，山崎広明，柴垣和夫 1973.『日本資本主義』(『帝国主戔の研究』第 6 巻) 青木書店。

海野福寿 1975.「貿易」古島敏雄，安藤良雄編『流通史 II』山川出版社所収。 西川博史 1977. 「産業二貿易構造（II）」石井寬治, 海野福寿, 中村政則編『近代 日本経済史を学ぶ』有斐閣所収。 桜谷前掲論文。

また，労貨・生産性論争については，論争の一方の論者による反批判。 桜谷腾美 1981. 「日本資本主義史の分析方法」『歴史学研究』496 (1981．9）pp. 36-45.

を参照。

10 西川前掲論文。西川は在華紡との関連で，海外市場を対象に，在華紡二低番手斐 品，「綿紡独占体」(日本)二高番手製品の分業化が成立したとしている。

11 現在の東南アジア地域を考えるならば，インドに含まれているビルマを別にする としても，英領マレー，仏領インドシナが欠けているが，前者は海峡植民地を経て 再出されることもあり搆成比上無視し得る程でしかないし，後者は日本に対する貿 易制限のため戦中戦後の一時期を除いて問題にならないため两地域は除くことにし た。したがって表にあげた 4 地域で十分東南アジア地域を代表し得ると考えた。

12 商工省商務局編 1929.『内外市場に於ける本邦輸出綿䋂物の現娤』p.1193（以 下『現勢』と略す)。

13 商工省商務局編 1925.『海外市場に於ける本邦綿布』は次のごとく記している。 「同国に翰入さるるものは多く香港及新嘉坡を経由し，本邦製品と雖も亦英国品と して取扱はれ居れり。是等は取扱郘人が為替変動により利害関係を顧慮するるのの 如し。」pp.346. (以下『本邦綿布』と略す。)

14 『現勢』p. 1193.

15 パラタパプーンも袴状民族衣装であるが，パライは拪染布，パプーソは系染布。

16 さきにも記したが，唒綿布も加工綿布ではあるが本稿では分けて用いる。また加 工綿布は大きく三つに分けられる。すなわち，染糸を用いて織った糹染あるいは先 染綿布，布を染めた布染あるいは後染綿布，布に柄をプリントした捺染線布である。 本稿では，系染，布染，捺染といら名称を用いる。 
両大戦間期日本綿織物の東南フジフ進出

17 タイのこの時期の加工綿布は捺染，布染が中心で，系染を中心として翰出してい た段階の当時の日本製品はとくに捺染ではたちうちできなかった。

18 『本邦綿布』p. 253.

19 『本邦綿布』『現勢』。

日本輸出綿織物同業組合聯合会 1928、『綿織物海外市場調查報告』。 を参照。

な抬前掲正田論文によれば，1926年の南洋貿易会議においてもこれらの問題，特 に運輸，倉庫，金融が問題とされていることがわかる。

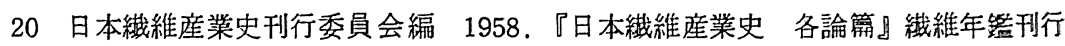
会。p. 33 .

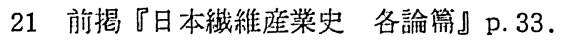

22 1960.『東棉40年史』p. 94 .

23 前掲『日本資本主義』参照。

24 前掲石井, 柳沢論文参照。

25 南洋団体連合会編 1942.『大南洋年鑑 (昭和17年版)』p. 31 .

26 三宅哲三郎 1978.「ジャガタラ談話」ジャガタラ友の会編『ジャカタラ閑話』 所収参照。

27 浜田恒一 1941.『蘭印の資本と民族経済』ダイヤモンド社。p. 196.

28 山本又六 1928.『南洋視察報告——南洋綿布事情』大幅織物研究会。 山本は次のように記している。

「和蘭カムブリックは生地は大部分英国マンチェスター製品にして和蘭独特の晒仕 上加工を施したるものなり。最近英国に於ても晒仕上加工の技術進歩し，和蘭に晒 加工の為輸出するもの著しく減少しつつありと雖, 多年の経験による技術の優越に 基く，犯し難き品位に至りては未だ遠く蘭品に及ばざるものの如し。」pp. 91-92.

29 バティク用布としてのキャンブリックは染色前に糊を落すため容易に糊が落ちな ければいけない。しかも小工場，家内工業で製作されるものであるゆえ管理はよい とは言えず，例え土がついても糊落しの際一緒に落ちなくてはならない。糊付につ いても産地により好みが違い，ジョクジャカルタ付近は硬糊仕上, 並糊仕上の硬仕 上，ソロ付近では並糊仕上の軟仕上，その他では軟糊仕上が好まれる（大阪市役所

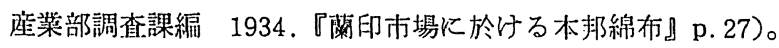

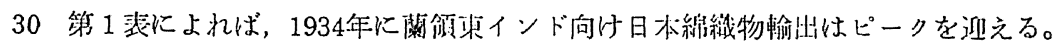
しかし闌領東インド側の統計では第10表のように1933年にピークを迎える。この差 
東南アジフ一歴史と文化一 No. 11，1982

は今のところ明らかではないが，1934年は，日蘭会商の年すなわちそれに先立って 綿布の翰入制限の割当制が行なわれた年であるので，1933年より多くなったとは考 えにくい。第10表がジャワ・マズラに限っているため，すなわちスマトラなどの外 領部の翰入が1934年に飛躍的に増加したとも考えることができようが，明らかでは ない。ここでは1933年ピークを一応とる。

31 加工綿布は 3 種を合計すると輸入綿布中最も多いものであり，かつ，日本側につ いて見ればそれは地方中小譏業地の綿布輸出の例として重要であり，闌領東インド 市場について見れば，バティクのような，いわば睛着的存在でない民恤衣料素材と して意味を持つ。しかし本稿は1930年代の日本綿䄉物の輸出增大を晒綿布を中心に 見たものであり，䊺数も限界なので他日に譲りたい。なおこれに関連する日本の中 小機業地の研究として, 山崎広明 1969. 「两大戦間期に扣ける遠州織物業の構造と運動」『経営志林』6一1. pp. 95-152 .

を参照されたい。

32 前揭『東棉40年史』。

33 1943.『日本綿花怢式会社50年史』。

34 前掲『日本綿花㧣式会社 50 年史』。

こうした大手商社と在留邦商との結びつきは興味深いが，その奏態は明らかでは ない。今後の課題としたい。

35 前掲『本邦綿布』。

36 サロンについては比較的華僑の力が弱く, 邦人商の活躍する余地があったようで ある(1933.『サロン類に就て』.静岡県浜松工業試験場)。

37 增田与 1971.『インドネシフ現代史』pp. 135 の三吉俊吉郎のインタビュー参照。

38 1937年のピークにおいて蘭領東インド, タイだけでなく, インドも晒綿布の增加 においてこれを達成しているのを見るのは與味深い。

（次ページ〈付表〉参照）

39 松尾大 1967.「ジャワ綿織物工業史」『アジア経済』8-6.

Matsuo Hiroshi. 1970. The Development of Javanese Cotton Industry. Tokyo:

The Institute of Developing Economies.

参照。

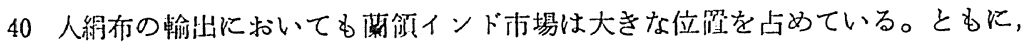
山崎広明 1975.『日本化䋐産業発達史諭』東京大学出版会参照。 
両大戦間期日本綿絇物の東南アジフ遥齿

付表 日本の輸出綿布仕向地別種類別推移

A 英領インド

\begin{tabular}{|r|r|r|r|r|}
\hline & 生 地 & \multicolumn{1}{|c|}{ 晒 } & 加 工 & 総 \\
\hline $1928(\mathrm{~S} .3)$ & 46,997 & 1,512 & 21,550 & 70,060 \\
$29(4)$ & 75,644 & 3,380 & 29,928 & 108,953 \\
$30(5)$ & 41,365 & 4,426 & 15,359 & 61,152 \\
$31(6)$ & 27,956 & 8,559 & 13,302 & 49,818 \\
$32(7)$ & 34,645 & 18,638 & 27,342 & 80,626 \\
$33(18)$ & 25,789 & 16,899 & 28,648 & 71,337 \\
$34(9)$ & 30,393 & 10,103 & 26,317 & 66,814 \\
$35(10)$ & 41,815 & 11,359 & 32,265 & 85,441 \\
$36(11)$ & 33,106 & 9,210 & 30,207 & 72,544 \\
$37(12)$ & 16,934 & 13,001 & 33,113 & 63,049 \\
$38(13)$ & 32,934 & 11,956 & 23,005 & 67,896 \\
$39(14)$ & 31,489 & 8,120 & 22,601 & 62,211 \\
\hline
\end{tabular}

同㯕成比

\begin{tabular}{|r|r|r|r|r|}
\hline $1928(\mathrm{~S} .3)$ & 67.0 & 2.1 & 30.7 & 100.0 \\
$29(5)$ & 69.4 & 3.1 & 27.4 & 100.0 \\
$30(5)$ & 67.6 & 7.2 & 25.1 & 100.0 \\
$31(5)$ & 56.1 & 17.1 & 26.7 & 100.0 \\
$32(4)$ & 42.9 & 23.1 & 33.9 & 100.0 \\
$33(5)$ & 36.1 & 23.6 & 40.1 & 100.0 \\
$34(5)$ & 45.4 & 15.1 & 39.3 & 100.0 \\
$35(10)$ & 48.9 & 13.2 & 37.7 & 100.0 \\
$36(11)$ & 45.6 & 12.6 & 41.6 & 100.0 \\
$37(12)$ & 26.8 & 20.6 & 52.5 & 100.0 \\
$38(13)$ & 48.5 & 17.6 & 33.8 & 100.0 \\
$39(14)$ & 50.6 & 13.0 & 36.3 & 100.0 \\
\hline
\end{tabular}

B タ イ

\begin{tabular}{|c|c|c|c|c|}
\hline & 生 地 & 晒 & 放 I & 站 \\
\hline 1928 (S.3) & 302 & 132 & 912 & 1,352 \\
\hline $29(4)$ & 658 & 350 & 2,802 & 3,810 \\
\hline $30(5)$ & 228 & 230 & 2,108 & 2,568 \\
\hline $31(6)$ & 63 & 144 & 576 & 784 \\
\hline $32(7)$ & 443 & 1,088 & 1,800 & 3,331 \\
\hline $33(8)$ & 645 & 2,271 & 3,846 & 6,763 \\
\hline $34(9)$ & 913 & 3,630 & 6,274 & 10,818 \\
\hline $35(10)$ & 1,294 & 3,079 & 9,049 & 13,423 \\
\hline $36(11)$ & 1,215 & 3,421 & 8,982 & 13,620 \\
\hline $37(12)$ & 1,478 & 5,173 & 9,496 & 16,148 \\
\hline $38(13)$ & 1,921 & 5,173 & 7,797 & 14,892 \\
\hline $39(14)$ & 1,824 & 5,226 & 7,099 & 14,151 \\
\hline
\end{tabular}

同丵成比

\begin{tabular}{|r|r|r|r|r|}
\hline $1928(\mathrm{~S} .3)$ & 22.3 & 9.7 & 67.4 & 100.0 \\
$29(4)$ & 17.2 & 9.1 & 73.5 & 100.0 \\
$30(5)$ & 8.8 & 8.9 & 82.0 & 100.0 \\
$31(6)$ & 8.0 & 18.3 & 73.4 & 100.0 \\
$32(4)$ & 13.2 & 32.6 & 54.0 & 100.0 \\
$33(5)$ & 9.5 & 33.5 & 56.8 & 100.0 \\
$34(9)$ & 8.4 & 33.5 & 57.9 & 100.0 \\
$35(10)$ & 9.6 & 22.9 & 67.4 & 100.0 \\
$36(11)$ & 8.9 & 25.1 & 65.9 & 100.0 \\
$37(12)$ & 9.1 & 32.0 & 58.8 & 100.0 \\
$38(13)$ & 12.8 & 34.7 & 52.3 & 100.0 \\
$39(14)$ & 12.8 & 36.9 & 50.1 & 100.0 \\
\hline
\end{tabular}

（資料）『紡聯月報』。

ちなみに人絹系の輸入增大は，勃興した織布業が綿系と人絹系の混織を行なった ためである。

41 森澤元三郎 1942.『東印度の工業と工業化問題』新経済社。pp.89.

42 本稿は東南アジア史学会1980年度春季大会での報告をまとめ加筆訂正したもので ある。それ以前にも早稲田大学社会科学研究所インドネシア部会, アジア政経学会 関東部会月例会などで中間報告の機会をいただき，貴重な助言を得ることができた。 この場を借りて謝意を表すると共に，それに拡えすることのできないことすあっ たのを柁びしたい。 
東南アジフ一歴史と文化一 No. 11,1982

\title{
Penetration of Japanese Cotton Cloth into Southeast Asia in the Interim of the Two World Wars
}

\author{
Yoshitada Murayama
}

The export of Japanese cotton cloth to Southeast Asia had two peaks in statistics: one in 1920's and the other in 1930's. There were remarkable difference in the kind of cloth between the two periods. In 1920's, the import of cotton cloth from Japan mainly consisted of grey cloth. On the other hand, the peak in 1930's was marked by bleached cotton fabric, especially in Dutch East Indies.

According to the common view, the Japanese cotton penetration in 1930's was due to their cheap price, which had been enabled to be achieved by the drastic fall of the exchange rate of Japanese Yen and the smaller cost of production of Japanese cotton industry at that time. But, in 1920's, the market of Southeast Asia attained to its maximum capacity to import Japanese grey cloth. If Japan had also continued to export grey cloth in 1930's, she couldn't, in spite of its cheap price, have enjoyed increasing volume of cotton cloth export in Southeast Asian market.

The Japanese cotton industry could find a new market of bleached cotton colth in Southeast Asia. But, this market was the last resort of the declining cotton industries of European countries, which were losing their market not only for grey cloth but for colored one. The struggle for the market share of Southeast Asia between Japan and European countrees was becoming keaner and keaner. In Dutch East Indies, this economic friction produced the import restriction by the colonial government and also the difficult Trade Negotiation between Japan and the Netherlands in 1934.

This paper attempts to analyze the above fact on the basis of the trade statistics available in Japan. We must notice that grey cloth and bleached 
両大戦間期日本綿織物の東南フジフ進出 one are different kinds of manufactured goods. Bleached fabric to export to Southeast Asia was enabled to presuppose the development of Japanese processing industry of cotton fabric in 1920's. And fortunately bleached fabric had larger share of imported cloth in Southeast Asia, particularly in Dutch East Indies. These facts reproduced Southeast Asia, which was the old market of Japanese cotton industry, as an important new market in 1930's. 